\title{
An Economics Analysis of Multiend and Automatic Reeling Units in Traditional and Non-Traditional Area of Tamil Nadu, India
}

\author{
D. Elumalai $^{1 *}$, P. Mohanraj ${ }^{1}$, R. Ramamoorthy ${ }^{1}$, C. Mohan ${ }^{2}$ and B. Poovizhiraja ${ }^{3}$ \\ ${ }^{1}$ Department of Sericulture, Forest Collage and Research Institute, \\ Mettupalayam, Coimbatore, Tamil Nadu, India \\ ${ }^{2}$ Department of Agricultural Entomology, \\ Palar agricultural college, Ambur, Vellore, Tamil Nadu, India \\ ${ }^{3}$ Department of Plant Protection, \\ Agricultural Collage and Research Institute, Madurai, Tamil Nadu, India \\ *Corresponding author
}

\begin{abstract}
A B S T R A C T
Sericulture is one of the rural-based agro industries with global reach. Some unique features of the Sericulture. The investigation was carried out during the year 2018-2019 in traditional and non-traditional area of Tamil Nadu. The traditional area such as Dharmapuri and Krishnagiri district was selected and these areas maximum reelers and twisters are producing raw silk and twisted silk. Non- traditional area such as Erode and Tiruppur district was selected. Using randomly selected from above the four district of Tamil Nadu. The study showed that multiend reelers obtained total expenditure of Rs.44671it worked per day running cost of machine. A per day capacity of multiend reeling machine is $100 \mathrm{kgs}$ of cocoon. Gross income realized to be of Rs. 49997 and net income of Rs. 5325. Next study observed that automatic basin reelers spending cost of Rs. 380,448 and net revenue of Rs. 531210. To calculated per day of net return in automatic reelers for Rs. 150761. Compared in multiend and automatic reelers are got income generations. But capacity of reeling per day high automatic machine due to improved reeling machine. Multiend reelers should be change in automatic machine government should be support financial and give training in multiend reelers. From twisting units result showed that total expenditure of Rs.81620/ per day and gross income of Rs. 84275/per day. The net return realized of Rs. 2655/per day. Next, constrains faced by reelers like fluctuation in cocoon, Absence of quality cocoons, Good water/reeling water and scarcity of labour etc. Apart from marketing problems like Fluctuation in silk prices was observed in the study. The study problems faced by twisters like High cost of twisting machines, High price fluctuation of raw silk, High transportation cost, Shortage of labour, Lack of skilled labour and fluctuation in twisted silk prices.
\end{abstract}

\section{Introduction}

Silk is one of the high valued, low volume natural quality fibers. Superiority of the end product, silk has been accepted as a natural textile fiber and as one of the high-value, lowvolume commodities to trade between the continents from time immemorial. Even today no other fabric matches its luster, durability, lightness, elegance and luxury. In India there are four types of silk produced like mulberry silk, tasar silk (temperate and tropical), muga silk and eri silk. Basis for production of raw silk is the yarn which is obtained out of cocoon spun by certain species of insects (Gupta, 2013). 
The Indian silk reeling industry has not made satisfactory qualitative and cost effective progress due to the technological inactivity and poor economic status of people associated in reeling activity. Thus, uneven growth in the industry will not only limited the prospects and scope of pre-cocoon production stages but also weakens the vital supply of quality silk yarn to the Indian silk weaving as well as fabric sectors. The silk reeling industry is largely traditional by nature. Among the three distinct devices of reeling, traditional charka, cottage and multi-end have been in use for many centuries and still dominates in terms of number as well as production.

While the 'cottage basins' which produces better quality over multiend are also more in Tamil Nadu. Now a day's quality of fabric with rich designs is produced on grade handlooms in Indian. Improved reeling machines such as multiend reeling and automatic reeling were installed to got good quality of raw silk yarn (Sonwalkar et al., 1987). Raw silk yarn length getting from 300 meters and 1200 meters depending upon the cocoon quality, silkworm race and reeling machine (Venugopal and Srinivasan, 1999).

That improve the quality of life of the reelers, labourers especially women and children who are engaged substantially in reeling sector. The industry is expected to produce international quality yarn to fulfill the needs of the domestic as well as international markets and thereby promote income redistribution in rural areas. Therefore, the improvement of this system needs to be evaluated.

Hence, present study conducted following objectives include to elucidate the economics of improved reeling machine (multiend and automatic basin) in Tamil Nadu. And also to identified constraints of improved reeling machine in Tamil Nadu.

\section{Materials and Methods}

This study was carried out in traditional and non-traditional area of Tamil nadu. The traditional area such as Dharmapuri and Krishnagiri district was selected and these areas maximum reelers and twisters are producing raw silk and twisted silk. Nontraditional area such as Erode and Tiruppur district was selected. Using randomly selected from above the four district of Tamil Nadu. The primary data necessary for the study was collected from the randomly selected units on the general socio economic characteristics, cost and returns of silk reeling, twisters and problems faced by silk industry units. The estimation of cost of production of raw silk under different (multi-end basin and automatic reeling units) gross income and net income from these systems of reeling and twisting. The frequency, percentage and rank were used as statistical measures to analyze the data. The major constraints taken into consideration were related to silk reeling.

\section{Garrett's ranking techniques}

Garrett's ranking techniques was adopted to analyse the problems faced by reelers in multiend and automatic basin. The respondents were asked to rank the given factors that were limiting the multiend and automatic basin.

The order of merit thus given by the respondents was converted into ranks using the following formula

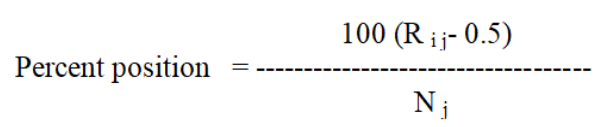

Where

$R_{i j}=$ Rank given for $i^{\text {th }}$ factor by $j^{\text {th }}$ individual.

$\mathrm{N}_{\mathrm{j}}=$ Number of factors ranked by $\mathrm{j}^{\text {th }}$ individual. 
By referring to the Garrett's table, the per cent positions estimated were converted into scores. Thus for each factor, the scores of the various respondents were added and the mean value was estimated. The means thus obtained for each of the attributes were arranged in descending order. The attributes with the highest mean value was considered as the most important one and the others followed in that order. The per cent position of each rank thus obtained was converted into scores by referring to tables given by Garrett.

\section{Results and Discussion}

\section{Raw silk production in multiend reeling}

The raw silk production in multiend reeling has been presented in Table 3.1. The purchased cost of cocoon in multiend reeler was Rs.37000 accounted for 82.82 per cent followed by minimum expenditure was incurred towards transportation cost of cocoon (Rs. 200; 0.44\%), packing material (Rs.200; 0.44\%), loading and unloading (Rs. $50 ; 0.11)$ and remaining belong to miscellaneous (Rs.120; 0.31\%). The total expenditure of procurement of cocoon in cottage reeling per unit per day was Rs.37570 was represented.

The processing cost of cottage reeling machine, majority of sample respondents higher labour charges in the multiend reeling units found were in reeling labour charges (Rs.1920; $4.29 \%$ ) followed by wastage of cleaning labour charges (Rs.1200; 2.68\%), cocoon cooking labour charges (Rs.960; 2.14\%) and winding labour charges (Rs.300; $1.64 \%)$.

The minimum expenditure was incurred towards fuel charges (Rs. 560; 1.25\%), firewood and water (Rs.400; 0.89\%), supervisor charges (Rs.300; 067\%) and electrical charges (Rs.88; 0.19\%). the total processing cost of multiend reeling per day per unit was Rs.6428 accounted for 14.38 per cent. Next, marketing cost of raw silk, majority of sample respondents found were in transportation and miscellaneous charges (Rs.400; $0.89 \%$ ) followed by transportation cost of raw silk (Rs.153.84; 0.34\%), packing materials (Rs.100; 0.22\%) and remaining belong to loading and unloading charges (Rs.20; $0.04 \%$ ). The total marketing cost of raw silk recorded was Rs.673.84 accounted for 1.50 per cent.

The total expenditure of multiend reeling per unit per day was Rs. 44671.84. The total retrun in main product was Rs. 46872 accounted for 93.74 per cent followed by product like the wastage of silk (Rs.2250; $4.50 \%$ ), defective cocoon (Rs.750; 1.50\%) and pupa (Rs.125; 0.25\%). The total return obtained per unit was Rs. 49997 with net returns from raw silk of Rs. 5325.16. The net return obtained from multiend reeling per unit per day was Rs.5325.16.

\section{Raw silk production in automatic reeling units}

The raw silk production in automatic reeling has been presented in Table 3.2. Among the total cost, the maximum cost was towards the reeling cocoons was Rs.350000 accounted for 92.11 per cent followed by minimum expenditure was incurred towards transportation cost of cocoon (Rs. 2000; $0.52 \%$ ), packing material (Rs.2200; 0.05\%), loading and unloading (Rs. 400; 0.10) and remaining belong to miscellaneous (Rs.300; $0.07 \%$ ). The total cost of procurement of cocoon in cottage reeling per unit per day was Rs.354900.

The processing cost of cottage reeling machine, majority of sample respondents higher labour charges in the automatic reeling units found were in reeling labour charges 
(Rs.2400; $0.63 \%$ ) followed by grading (Rs.300; 0.075), wastage and cleaning (Rs.480; 0.12\%), winding (Rs.720; 0.18\%), cocoon cooking labour charges (Rs.480; $0.12 \%$ ) and brushing labour charges (Rs.240; $0.06 \%$ ), byproduct (Rs.700; 0.18), packing (Rs.250; 0.06\%) and remaining belongs to supervisor (Rs.900; 0.23\%), account maintenance (Rs.600; 0.15\%). The minimum expenditure was incurred towards fuel charges (Rs. 5600; $1.47 \%$ ), firewood (Rs.3500; 0.92\%), water charges (Rs.4000; $1.05 \%$ ) and electrical charges (Rs.2500; $0.65 \%)$. The total processing cost of multiend reeling per day per unit was Rs.22730 accounted for 5.85 per cent.

In automatic reeling units, marketing cost of raw silk, maximum cost of towards the transportation cost of raw silk (Rs.400; $0.89 \%$ ) followed by transportation and miscellaneous human charges (Rs.720; $0.18 \%$ ), packing materials (Rs.480; 0.12\%) and remaining belong to loading and unloading charges (Rs.80; 0.02\%). The total marketing cost of raw silk recorded was Rs. 2818.40 accounted for 0.74 per cent

The total expenditure of multiend reeling per unit per day was Rs. 380448.40. The total retrun in main product was Rs. 484615.38 accounted for 91.22 per cent followed by product like the wastage of silk (Rs.28845; $5.43 \%$ ), defective cocoon (Rs.12500; 5.43\%) and pupa (Rs.5250; 0.98\%). The total return obtained per unit was Rs. 531210.38 with net returns from raw silk of Rs. 150761.98. The net return obtained from multiend reeling per unit per day was Rs. 150761.98.

\section{Twisted silk production in twisting unit}

The Twisted silk production in twisting unit has been presented in Table 3.3. In twisting units, the purchased cost of raw silk was Rs.78750 accounted for 96.48 per cent. The minimum cost was incurred towards transportation and miscellaneous charges (Rs. 450; $0.55 \%$ ), loading and transportation cost of raw silk (Rs.250; 0.30\%), packing materials (Rs. 120; 0.14\%) and remaining belong to unloading (Rs. 20; 0.02\%). the total procurement cost of raw silk in twisting unit per unit per day was Rs.79590.

About, processing cost of labour in twisting machine majority of sample respondents found were high wages rate was incurred towards in winder charges (Rs.480; 0.58\%) followed by same charges in double, twister and re-reeler (Rs.240; 0.23\%) and electrical charges (Rs.80; 0.09. the total processing cost of twisting unit per day per unit was Rs.1280 accounted for 1.56 per cent. Marketing cost of twisted silk, maximum cost was incurred towards in transportation charges and miscellaneous (Rs. 400; 0.49\%) followed by packing materials (Rs.100; 0.12\%), transportation cost of raw silk (Rs.250; $0.30 \%$ ) The total marketing cost of twisted silk recorded was Rs.750 accounted for 0.91 per cent.

The total expenditure of twisting unit per unit per day was Rs. 81620. The total retrun in main product was Rs. 84150 accounted for 99.85 per cent followed by -product like the wastage of silk (Rs.125; $0.15 \%$ ). The total return obtained per unit was Rs. 81620 with net returns from raw silk of Rs. 2655. The net return obtained from twisting unit per unit per day was Rs.2655.

\section{Constraints faced by improved machine reelers}

In the present study, main problems which were observed in procurement of cocoon like fluctuation in cocoon Absence of quality cocoons, Poor information of market etc. In processing fore most constraints was identified such as Poor quality cocoons, Good 
water/reeling water and scarcity of labour etc. Apart from marketing problems like Fluctuation in silk prices, Non-availability of market information and Transportation problem.

\section{Problems faced by tiwsters}

The sample farmers were asked about the various problems faced by them in twisting. The identified problems were listed out and the twisters were asked to rank the problems.
Garrett's ranking techniques was used to find out the final ranks and the results are presented in the Table.3.5. The study are several problems faced by twisters like High cost of twisting machines, High price fluctuation of raw silk and High transportation cost. From the table processing problems such as Shortage of labour, Lack of skilled labour and Lack of technical guidance etc. Next, marketing constraints faced twisters like fluctuation in twisted silk prices, high transportation cost and import silk.

Table.1.1 Raw silk production in multiend reeling 8 basins/per day

(Cost)

\begin{tabular}{|c|c|c|c|c|c|c|c|}
\hline S.No & Particulars & Unit & Quantity & $\begin{array}{l}\text { Price/unit } \\
\text { (Rs.) }\end{array}$ & $\begin{array}{l}\text { Amount } \\
\text { (Rs.) }\end{array}$ & Percentage & $\begin{array}{c}\text { Cost of per } \\
\text { kg }\end{array}$ \\
\hline \multicolumn{8}{|c|}{ I. Procurement of cocoon } \\
\hline 1 & Cocoon purchased & $\mathrm{Kg}$ & 100 & 370 & 37000 & 82.82 & 2486.55 \\
\hline 2 & Packing materials & Nos. & 2 & 100 & 200 & 0.44 & 13.44 \\
\hline 3 & Loading/unloading & - & - & - & 50 & 0.11 & 3.36 \\
\hline 4 & $\begin{array}{l}\text { Transportation cost of } \\
\text { cocoon }\end{array}$ & Kg. & 100 & 2 & 200 & 0.44 & 13.44 \\
\hline \multirow[t]{2}{*}{5} & Miscellaneous & - & - & - & 120 & 0.31 & 8.06 \\
\hline & \multicolumn{4}{|c|}{ Total Procurement cost of cocoon (I) } & 37570 & 84.10 & 2524.86 \\
\hline \multicolumn{8}{|c|}{ II. Processing } \\
\hline \multirow[t]{5}{*}{1} & \multicolumn{5}{|l|}{ Labour charges } & & \\
\hline & \begin{tabular}{l|l}
1.1 & Reeling labour
\end{tabular} & Nos. & 8 & 240 & 1920 & 4.29 & 16.12 \\
\hline & $\begin{array}{l}\text { Wastage cleaning } \\
\text { Labour }\end{array}$ & Nos. & 5 & 240 & 1200 & 2.68 & 80.64 \\
\hline & Winding & Nos. & 2 & 300 & 600 & 1.34 & 40.32 \\
\hline & Cooking & Nos. & 4 & 240 & 960 & 2.14 & 64.51 \\
\hline 2 & Firewood & - & - & - & 400 & 0.89 & 26.88 \\
\hline 3 & Electrical charges & Unit & 11 & 8 & 88 & 0.19 & 5.91 \\
\hline 4 & Water & - & - & - & 400 & 0.89 & 26.88 \\
\hline 5 & Fuel & Lit. & 8 & 70 & 560 & 1.25 & 37.63 \\
\hline \multirow[t]{2}{*}{6} & Supervisor & Nos. & 1 & 300 & 300 & 0.67 & 20.16 \\
\hline & \multicolumn{4}{|c|}{ Total Processing charges (II) } & 6428 & 14.38 & 431.98 \\
\hline \multicolumn{8}{|c|}{ III. Marketing cost of raw silk } \\
\hline 1 & $\begin{array}{l}\text { Transportation cost of raw } \\
\text { silk }\end{array}$ & $\mathrm{Kg}$. & 14.88 & 10.30 & 153.84 & 0.34 & 10.30 \\
\hline 2 & Packing materials & Nos. & 1 & 100 & 100 & 0.22 & 6.72 \\
\hline 3 & Loading/ unloading & - & - & - & 20 & 0.04 & 1.34 \\
\hline \multirow[t]{3}{*}{4} & $\begin{array}{l}\text { Transport charges and } \\
\text { Miscellaneous }\end{array}$ & - & & & 400 & 0.89 & 26.88 \\
\hline & \multicolumn{4}{|c|}{ Total marketing cost of raw silk (III) } & 673.84 & 1.50 & 45.28 \\
\hline & & & tal expend & re (I+II+III) & 44671.84 & 100.00 & 3002.13 \\
\hline
\end{tabular}


Table.1.2 Returns

\begin{tabular}{|c|c|c|c|c|c|c|c|}
\hline S.No & Details & Unit & Quantity & $\begin{array}{l}\text { Price/unit } \\
\text { (Rs.) }\end{array}$ & $\begin{array}{c}\text { Amount } \\
\text { (Rs.) }\end{array}$ & Percentage & Per kg \\
\hline \multicolumn{8}{|c|}{ 1.Main product } \\
\hline & $\begin{array}{l}\text { Quality of raw silk } \\
\text { (18 to } 20 \text { Diner) (6.72 } \\
\text { Renditta) }\end{array}$ & Kg. & 14.88 & 3150 & 46872 & 93.74 & 3150 \\
\hline \multicolumn{8}{|c|}{ 2. Byproduct } \\
\hline & Sale of pupa & $\mathrm{Kg}$. & 25 & 5 & 125 & 0.25 & 8.40 \\
\hline & Wastages of silk & $\mathrm{Kg}$. & 3 & 750 & 2250 & 4.50 & 151.20 \\
\hline & Defective cocoon & $\mathrm{Kg}$. & 3 & 250 & 750 & 1.50 & 50.40 \\
\hline & \multicolumn{4}{|c|}{ Total returns } & 49997 & 100.00 & 3360.01 \\
\hline
\end{tabular}

Table.1.3 Cost and returns of multiend reelers

\begin{tabular}{|r|l|r|}
\hline S.No & Details & \multicolumn{1}{|l|}{$\begin{array}{l}\text { Amounts } \\
\text { (Rs.) }\end{array}$} \\
\hline $\mathbf{1}$ & Total expenditure & 44671.84 \\
\hline $\mathbf{2}$ & Total returns & 49997 \\
\hline $\mathbf{3}$ & Net returns & 5325.16 \\
\hline
\end{tabular}

Table.2.1 Raw silk production in automatic reeling units 400 ends/per day (Cost)

\begin{tabular}{|l|l|l|r|r|r|r|r|}
\hline S.No & Particulars & Unit & Quantity & $\begin{array}{c}\text { Price/unit } \\
\text { (Rs.) }\end{array}$ & $\begin{array}{l}\text { Amount } \\
\text { (Rs.) }\end{array}$ & Percentages & $\begin{array}{l}\text { Cost of per } \\
\text { kg }\end{array}$ \\
\hline I. Procurement of cocoon & & & & & & \\
\hline $\mathbf{1}$ & Cocoon purchased & Kg. & 1000 & 350 & 35000 & 91.99 & 2275.09 \\
\hline $\mathbf{2}$ & Packing materials & Nos. & 20 & 110 & 2200 & 0.57 & 14.30 \\
\hline $\mathbf{3}$ & Loading/unloading & - & - & - & 400 & 0.10 & 2.60 \\
\hline $\mathbf{4}$ & $\begin{array}{l}\text { Transportation cost of } \\
\text { cocoon }\end{array}$ & Kg. & 1000 & 2 & 2000 & 0.52 & 13.00 \\
\hline $\mathbf{5}$ & Miscellaneous & - & - & - & 300 & 0.07 & 1.95 \\
\hline & & & & & & & \\
\hline
\end{tabular}




\begin{tabular}{|c|c|c|c|c|c|c|c|c|}
\hline & 1.5 & Supervisor & Nos. & 2 & 450 & 900 & 0.23 & 5.85 \\
\hline & 1.6 & $\begin{array}{l}\text { Account } \\
\text { maintenance }\end{array}$ & Nos. & 2 & 300 & 600 & 0.15 & 3.90 \\
\hline & 1.7 & Byproduct & Nos. & 2 & 350 & 700 & 0.18 & 4.55 \\
\hline & 1.8 & Packing & Nos. & 1 & 250 & 250 & 0.06 & 1.62 \\
\hline 2 & \multicolumn{2}{|c|}{ Firewood } & - & - & - & 3500 & 0.92 & 22.75 \\
\hline 3 & \multicolumn{2}{|c|}{ Electrical charges } & Unit & 357 & 7 & 2500 & 0.65 & 16.25 \\
\hline 4 & \multicolumn{2}{|c|}{ Water } & - & - & - & 4000 & 1.05 & 26.00 \\
\hline 5 & \multirow{2}{*}{\multicolumn{2}{|c|}{ Fuel }} & Lit & 80 & 70 & 5600 & 1.47 & 36.40 \\
\hline & & & \multicolumn{3}{|c|}{ Total Processing charges (II) } & 22730 & 5.85 & 147.75 \\
\hline \multicolumn{9}{|c|}{ III. Marketing cost of raw silk } \\
\hline 1 & \multicolumn{2}{|c|}{$\begin{array}{l}\text { Transportation cost of } \\
\text { raw silk }\end{array}$} & $\mathrm{Kg}$. & 153.84 & 11.83 & 1538.40 & 0.40 & 10.00 \\
\hline 2 & \multicolumn{2}{|c|}{ Packing materials } & Nos. & 4 & 120 & 480 & 0.12 & 3.12 \\
\hline 3 & \multicolumn{2}{|c|}{ Loading/ unloading } & - & - & - & 80 & 0.02 & 0.52 \\
\hline 4 & \multicolumn{2}{|c|}{ Miscellaneous } & - & & & 720 & 0.18 & 4.86 \\
\hline & \multicolumn{5}{|c|}{ Total marketing cost of raw silk (III) } & 2818.40 & 0.74 & 18.32 \\
\hline & \multicolumn{5}{|c|}{ Total expenditure (I+II+III) } & $380,448.40$ & 100.00 & 2473.01 \\
\hline
\end{tabular}

Table.2.2 Returns

\begin{tabular}{|c|c|c|c|c|c|c|c|}
\hline S.No & Details & Unit & Quantity & $\begin{array}{l}\text { Price/unit } \\
\text { (Rs.) }\end{array}$ & $\begin{array}{c}\text { Amount } \\
\text { (Rs.) }\end{array}$ & Percentage & $\begin{array}{l}\text { Cost of } \\
\text { per kg }\end{array}$ \\
\hline \multicolumn{8}{|c|}{ 1.Main product } \\
\hline & $\begin{array}{l}\text { Quality of raw silk } \\
\text { (18 Diner) (6.52 } \\
\text { Renditta) }\end{array}$ & $\mathrm{Kg}$. & 153.84 & 3150 & 484615.38 & 91.22 & 3150 \\
\hline \multicolumn{8}{|c|}{ 2. Byproduct } \\
\hline & $\begin{array}{l}\text { Crushed pupa in } \\
\text { preparation of cooling } \\
\text { cloth }\end{array}$ & $\mathrm{Kg}$. & 2.5 & 2100 & 5250 & 0.98 & 34.12 \\
\hline & Wastages of silk & $\mathrm{Kg}$. & 38.46 & 750 & 28845 & 5.43 & 187.50 \\
\hline & Defective cocoon & $\mathrm{Kg}$. & 50 & 250 & 12500 & 2.35 & 81.25 \\
\hline & \multicolumn{4}{|c|}{ Total returns } & 531210.38 & 100.00 & 3453 \\
\hline
\end{tabular}

Table.2.3 Cost and returns of automatic reelers

\begin{tabular}{|c|l|c|}
\hline S.No & Details & $\begin{array}{c}\text { Amounts } \\
\text { (Rs.) }\end{array}$ \\
\hline $\mathbf{1}$ & Total expenditure & 380448.40 \\
\hline $\mathbf{2}$ & Total returns & 531210.38 \\
\hline $\mathbf{3}$ & Net returns & 150761.98 \\
\hline
\end{tabular}


Table.3.1 Twisted silk production in twisting unit Machine per day (Cost )

\begin{tabular}{|c|c|c|c|c|c|c|c|c|}
\hline S.No & \multicolumn{2}{|c|}{ Particulars } & Unit & Quantity & $\begin{array}{l}\text { Price/unit } \\
\text { (Rs.) }\end{array}$ & $\begin{array}{l}\text { Amount } \\
\text { (Rs.) }\end{array}$ & Percentage & $\begin{array}{c}\text { Cost of per } \\
\text { kg }\end{array}$ \\
\hline \multicolumn{9}{|c|}{ I. Procurement of raw silk } \\
\hline 1 & \multicolumn{2}{|c|}{ Purchased in raw silk } & $\mathrm{Kg}$. & 25 & 3150 & 78750 & 96.48 & 3181.81 \\
\hline 2 & \multicolumn{2}{|c|}{ Packing materials } & Nos. & 1 & 120 & 120 & 0.14 & 4.84 \\
\hline 3 & \multicolumn{2}{|c|}{ Loading/unloading } & - & - & - & 20 & 0.02 & 0.80 \\
\hline 4 & \multicolumn{2}{|c|}{$\begin{array}{l}\text { Transportation cost of } \\
\text { cocoon }\end{array}$} & $\mathrm{Kg}$. & 25 & 10 & 250 & 0.30 & 10.10 \\
\hline \multirow[t]{2}{*}{5} & \multicolumn{2}{|c|}{ Miscellaneous } & - & - & - & 450 & 0.55 & 18.18 \\
\hline & \multicolumn{5}{|c|}{ Total Procurement cost of raw silk (I) } & 79590 & 97.51 & 3215.75 \\
\hline \multicolumn{9}{|c|}{ II. Processing } \\
\hline \multirow[t]{5}{*}{1} & \multicolumn{6}{|c|}{ Labour charges } & & \\
\hline & 1.1 & Winders & Nos. & 2 & 240 & 480 & 0.58 & 19.39 \\
\hline & 1.2 & Doubler & Nos. & 1 & 240 & 240 & 0.29 & 9.69 \\
\hline & 1.2 & Twister & Nos. & 1 & 240 & 240 & 0.29 & 9.69 \\
\hline & 1.4 & Re-reeler & Nos. & 1 & 240 & 240 & 0.29 & 9.69 \\
\hline \multirow[t]{2}{*}{2} & \multirow{2}{*}{\multicolumn{2}{|c|}{ Electrical charges }} & Unit & 10 & 8 & 80 & 0.09 & 3.23 \\
\hline & & & \multicolumn{3}{|c|}{ Total Processing charges (II) } & 1280 & 1.56 & 51.71 \\
\hline \multicolumn{9}{|c|}{ III. Marketing cost of raw silk } \\
\hline 1 & \multicolumn{2}{|c|}{$\begin{array}{l}\text { Transportation cost of } \\
\text { raw silk }\end{array}$} & $\mathrm{Kg}$. & 24.75 & 10.10 & 250 & 0.30 & 10.10 \\
\hline 2 & \multicolumn{2}{|c|}{ Packing materials } & Nos. & 1 & 100 & 100 & 0.12 & 4.04 \\
\hline \multirow[t]{3}{*}{4} & \multicolumn{2}{|c|}{ Miscellaneous } & - & & & 400 & 0.49 & 16.16 \\
\hline & \multicolumn{5}{|c|}{ Total marketing cost of raw silk (III) } & 750 & 0.91 & 30.30 \\
\hline & \multicolumn{5}{|c|}{ Total expenditure (I+II+III) } & 81620 & 100.00 & 3297.77 \\
\hline
\end{tabular}

Table.3.2 Returns

\begin{tabular}{|c|c|c|c|c|c|c|c|}
\hline S.No & Details & Unit & Quantity & $\begin{array}{l}\text { Price/unit } \\
\text { (Rs.) }\end{array}$ & $\begin{array}{c}\text { Amount } \\
\text { (Rs.) }\end{array}$ & Percentage & $\begin{array}{l}\text { Cost of } \\
\text { per kg }\end{array}$ \\
\hline \multicolumn{8}{|c|}{ 1.Main product } \\
\hline & $\begin{array}{l}\text { Quality of } \\
\text { twisted silk }\end{array}$ & Saree & 24.75 & 3400 & 84150 & 99.85 & 3400 \\
\hline \multicolumn{8}{|c|}{ 2. Byproduct } \\
\hline & Wastages of silk & Gm. & 0.25 & 500 & 125 & 0.15 & 20.20 \\
\hline & \multicolumn{4}{|c|}{ Total returns } & 84275 & 100.00 & 3420.20 \\
\hline
\end{tabular}

Table.3.3 Cost and returns of twisters

\begin{tabular}{|c|l|r|}
\hline S.No & Details & Amounts (Rs.) \\
\hline $\mathbf{1}$ & Total expenditure & 81620 \\
\hline $\mathbf{2}$ & Total returns & 84275 \\
\hline $\mathbf{3}$ & Net returns & 2655 \\
\hline
\end{tabular}


Table.4 Constraints faced by improved machine reelers

\begin{tabular}{|c|l|c|c|c|c|}
\hline S.No & \multicolumn{1}{|c|}{ Problmes } & \multicolumn{2}{c|}{ Multiend } & Reeling & \multicolumn{2}{c|}{ Automatic Reeling } \\
\cline { 3 - 6 } & & Score & Rank & Score & Rank \\
\hline $\mathbf{A}$ & Procurement problems & & & & \\
\hline $\mathbf{1}$ & Fluctuation in cocoon prices & 1434 & I & 144 & I \\
\hline $\mathbf{2}$ & Absence of quality cocoons & 1347 & II & 134 & II \\
\hline $\mathbf{3}$ & Poor information of market & 1209 & III & 96 & IV \\
\hline $\mathbf{4}$ & Poor market facilities & 1010 & IV & 107 & III \\
\hline B & Processing problems & 1404 & I & 148 & I \\
\hline $\mathbf{1}$ & Poor quality cocoons & 1360 & II & 128 & III \\
\hline $\mathbf{2}$ & Good water/reeling water & 1328 & III & 140 & II \\
\hline $\mathbf{3}$ & Scarcity of labour & 1051 & IV & 87 & IV \\
\hline $\mathbf{4}$ & High labour cost & 808 & V & 80 & V \\
\hline $\mathbf{5}$ & High cost of silk reeling machines & & & & \\
\hline $\mathbf{C}$ & Marketing problems & 1488 & I & 148 & I \\
\hline $\mathbf{1}$ & Fluctuation in silk prices & 1210 & III & 140 & III \\
\hline $\mathbf{2}$ & Non-availability of market information & 1388 & II & 142 & II \\
\hline $\mathbf{3}$ & Transportation problems & & & \\
\hline
\end{tabular}

Table.5 Problems faced by twisters

\begin{tabular}{|c|l|c|c|}
\hline S.No & \multicolumn{1}{|c|}{ Problems } & \multicolumn{2}{c|}{ Twisters (N=25) } \\
\cline { 3 - 4 } & & & Mean score \\
\hline & Procurment problmes & & \\
\hline $\mathbf{1}$ & High cost of twisting machines & 16.30 & I \\
\hline $\mathbf{2}$ & High price fluctuation of raw silk & 15.70 & II \\
\hline $\mathbf{3}$ & High transportation cost & 13.40 & III \\
\hline $\mathbf{4}$ & Supply of raw materials in untime & 6.20 & IV \\
\hline & Processing problems & & \\
\hline $\mathbf{1}$ & Shortage of labour & 17.29 & I \\
\hline $\mathbf{2}$ & Lack of skilled labour & 16.20 & II \\
\hline $\mathbf{3}$ & Lack of technical guidance & 13.02 & III \\
\hline $\mathbf{4}$ & Quality of raw silk are not available & 11.12 & IV \\
\hline & Marketing problems & 18.28 & \\
\hline $\mathbf{1}$ & Fluctuation in twisted silk prices & 17.48 & I \\
\hline $\mathbf{2}$ & High transportation cost & 12.30 & IV \\
\hline $\mathbf{3}$ & Import silk & 12.29 & V \\
\hline $\mathbf{4}$ & Delay in cash & 15.60 & III \\
\hline $\mathbf{5}$ & Non-availability of market & & \\
\hline & information & & \\
\hline
\end{tabular}


The present study draws the following implications for the perspective development of sericulture in long run in the study regions. The study indicates that silk industry has a good possible to create smart income for the reelers. It is more labour intensive and has low capital requirement and serve a good option for silk reelers to gain meaningful employment and income all around the year.

In order to breakdown the cost of production, the reelers should be motivated and demonstrated with the adoption of improved reeling. Compared the multiend and automatic basin reelers got high income generating and also to be getting quality of raw silk yarn due these are improved technologies machine.

Only 5 per cent of reelers are running in automatic basin because of these machine are cost of expenditure was high compared with multiend basin. Hence government should be give the subsidy and motivated the reelers. Then Apart from that twisters only 25 per cent of twisters are running in twisting machine. Hence, Increase the twisting machine government gives the subsidy and motivated the twisters.

\section{References}

Sonwalkar, T.N., Lakshipathaiah, B.N., and Nagabushaniah, Y.V., 1987, Different system of reeling and their influence on quality of silk. National workshop on silk industry in India ancient traditional to 21th century, April, CSTRI, Bangalore, pp.83-86.

Gupta, Harshit. 2013. Employment generating factors in sericulture in Karnataka and marketing research on promotional strategies of KSZC. Fiscal Policy Institute, project report, Indian Institute of Management, Lucknow.

Venugopal, S, and R Srinivasan. 1999. "A managerial analysis of the performance of the Silk reeling industry in India through simulation." International journal of information and management sciences, 10 (4):23-40.

\section{How to cite this article:}

Elumalai. D., P. Mohanraj, R. Ramamoorthy, C. Mohan and Poovizhiraja. B. 2020. An Economics Analysis of Multiend and Automatic Reeling Units in Traditional and NonTraditional Area of Tamil Nadu, India. Int.J.Curr.Microbiol.App.Sci. 9(07): 489-498. doi: https://doi.org/10.20546/ijcmas.2020.907.054 